ISSN: 2528-4002 (media online)

ISSN: 2355-892X (print)

Online: http://e-journal.sari-mutiara.ac.id/index.php/KesehatanMasyarakat

DOI: https://doi.org/10.51544/jkmlh.v6i2.1901

\title{
ANALISIS EFISIENSI ENERGI LISTRIK PADA BOHLAM LAMPU MENGGUNAKAN SISTEM PANEL SURYA
}

\author{
Eti Elisa \\ Pendidikan Fisika, Universitas Jember \\ Kampus Tegal Boto, Jl. Kalimantan No.37, Krajan Timur, \\ Sumbersari,Kabupaten Jember, Jawa Timur \\ *Email: etielisa29@gmail.com
}

\begin{abstract}
ABSTRAK
Tujuan dari penelitian ini adalah untuk mengetahui efisiensi dari penggunaan panel surya yang diterapkan pada lampu bohlam. Tujuan dari penelitian ini juga untuk menjelaskan cara kerja dari panel surya beserta mengetahui keuntungan akurasi dalam pelaksanaannya. Metode yang digunakan adalah metode review jurnal mengenai panel surya dan energy listrik pada lampu bohlam, menggunakan jurnal yang telah diakui oleh nasional maupun international .
\end{abstract}

Katakunci: Energi, Panel Surya, Listrik

\section{ABSTRACT}

The purpose of this study was to determine the efficiency of the use of solar panels applied to light bulbs. The purpose of this research is also to explain how the solar panels work and to find out the advantages of accuracy in their implementation. The method used is the journal review method regarding solar panels and electrical energy in light bulbs, using journals that have been recognized both nationally and internationally.

Keywords: Energy, Solar Panels, Electricity

\section{PENDAHULUAN}

Menurut bank dunia saat ini Indonesia menggunakan listrik sebesar 883,92 kg minyak untuk listrik pertahunnya ditinjau dari tahun 2000 sampai 2014, hal tersebut menurut detoks juga didukung dengan minat warga menggunakan listrik semakin meningkat setiap tahunnya menjadi $84,35 \%$ pada 2014 menjadi $98,89 \%$ pada 2019 . Dengan penggunaan listrik terus menerus dapat merusak dan membahayakan lingkungan. Didukung dengan perkembangan teknologi seperti AC, Handphone, Kulkas, TV dan alat elektronika lainnya akan membuat listrik semakin sering digunakan baik dalam kegiatan rumahtangga maupun bisnis.

Penggunaan listrik banyak terbuang untuk kegiatan rumahtangga seperti charger yang tidak dilepas, penggunaan lampu yang terlalu lama, penggunaan listrik untuk peralatan rumahtangga seperti kompor listrik, setrika, mesin cuci dan magic com yang menyebabkan listrik terus menerus digunakan oleh masyarakat.

Di dalam kehidupan, manusia selalu menggunakan listrik sebagai produksi ekonomi sehari hari. Proses pembuatan kebutuhan di dalam pabrik menggunakan daya listrik untuk menggunakan mesin mesin yang bekerja menggantikan manusia atau mempermudah kerja manusia. Manusia sendiri termasuk dalam golongan konsumtif, yaitu makhluk yang terus menerus menggunakan atau mengkonsumsi barang untuk memenuhi kebutuhan dan keinginan diri sendiri. Sifat konsumtif tersbut menyebabkan manusia haus akan perkembangan teknologi dengan memanfaatkan listrik itu sendiri. Setiap rumah dialiri listrik sebesar 450 watt atau 900 watt untuk memenuhi kebutuhan alat electron $\mathrm{k}$ manusia. Dengan aliran listrik sebesar 450 watt atau 900 watt disetiap rumah dapat menggunakan berbagai macam 
Jurnal Kesehatan Masyarakat dan Lingkungan Hidup

Vol. 6 No. 22021

ISSN: 2528-4002 (media online)

ISSN: 2355-892X (print)

Online: http://e-journal.sari-mutiara.ac.id/index.php/KesehatanMasyarakat

DOI: https://doi.org/10.51544/jkmlh.v6i2.1901

elektonika, manusia membutuhkan listrik

dalam rumah diutamakan untuk penerangan

rumah begitu pula di gedung maupun jalan

sebagai penerangan utama. Dengan menggunakan lampu bohlam disetiap ruangan akan membantu manusia melaksanakan kegiatan disaat malam hari dari jam 7 malam sampai jam 4 pagi kebanyak rumah menyalakan lampu non stop sampai pagi menjelang. Hal tersebut menyebabkan lampu bohlam menjadi sumber penggunaan listrik terbanyak dan paling sering digunakan oleh manusia.

Teknologi sel surya untuk sumber energy masa depan telah mengalami kemajuan akhir-akhir ini. Pada tahun 1833 Charles Fritts menciptakan panel surya untuk pertama kali, dimana alat tersebut berfungsi untuk menghasilkan tenaga listrik tanpa menggunakan minyak. Panel tersebut menggunakan sel surya atau menyerap panas dari matahari yang akan diubah menjadi energy listrik. Panel surya ini berguna untuk menghemat penggunaan listrik.

Panel surya mengalami perkembangan terus menerus disetiap tahunnya hingga menjadi sempurna pada tahun 1954 oleh Bell Laboratories. Panel surya ini disebutkan dapat mengefisiensi penggunaan minyak untuk menghasilkan listrik dan dapat memberikan efek yang lebih bagus bagi bumi memiliki potensi yang luar biasa, dan dapat meningkatkan industry sel surya ketingkat yang baru.

Berdasarkan uraian diatas, peneliti tertarik untuk mengetahui efisiensi energy listrik pada bohlam lampu menggunakan sistem panel surya .

\section{Perumusan Masalah}

Apakah penggunakan panel surya dapat mengefisiensi kebutuhan rumah dalam penggunaan listrik pada lampu bohlam .

\section{Hipotesis}

Hipotesis dalam penelitian ini adalah penggunaan panel surya dapat mengefisiensi penggunaan listik dan

menghemat penggunaan minyak untuk menghasilkan listrik pada lampu bohlam didalam rumah serta menjadikan lingkungan lebih bersih.

\section{Tujuan Penilitian}

Tujuan penelitian untuk menganalisis penggaruh panel surya dalam rangka mengefisiensi listrik lampu bohlam dalam rumahtangga.

\section{Manfaat Penelitian}

Sebagai bahan masukan responden dalam penggunaan panel surya menggantikan daya listrik PLN yang digunakan pada lampu bohlam yang ada dirumah.

\section{METODE PENELITIAN}

Penelitian ini menggunakan metode, persiapan lengkap dan karakterisasi pratinjau perhitungan biaya penggunaan listrik menggunakan PLN dengan penggunaan listrik menggunakan panel surya atau solar cell.

\section{HASIL DAN PEMBAHASAN}

Dalam rumah tangga, listrik menjadi komponen penting untuk menjalankan kehidupan sehari hari. Menjadi komponen utama dalam keberlangsungan hidup manusia membuat pemerintah memberikan fasilitas penggunakan listrik secara umum yaitu PLN. PLN menjadi pusat utama dalam pengaliran listrik, disetiap rumah akan menerima aliran listrik yang dikoordinir dan akan dibayarkan setiap bulannya ke PLN.

Rata rata rumahtangga sekarang menggunakan besaran meter sekitar 2200 $\mathrm{Va}$, dimana didalamnya terdapat penggunaan alat elektronika seperti lampu, kulkas, kipas, AC dan lain sebagainya. Dari alat elektronik tersebut ,lampu memiliki komponen penting dalam aspek penerangan dimalam hari maupun sore hari untuk membantu manusia saat hari menjelang gelap. Sehingga, lampu sering menjadi pengeluaran besar dalam tagihan listrik perbulannya. 
Jurnal Kesehatan Masyarakat dan Lingkungan Hidup

ISSN: 2528-4002 (media online)

ISSN: 2355-892X (print)

Online: http://e-journal.sari-mutiara.ac.id/index.php/KesehatanMasyarakat

DOI: https://doi.org/10.51544/jkmlh.v6i2.1901

Jika diketahui bahwa rata rata setiap rumah menggunakan sekitar 30 lampu bohlam dengan kapsitas sebesar 5 wattdan rata rata digunakan pada pukul 17.00 - 05.00 pagi (12 jam) maka dapat diketahui tagihan yang dibutuhkan sebesar :

1 lampu 5 watt $=0,005 \mathrm{kWh}$

30 lampu x 0,005 kWh =0,15 kWh

Digunakan selama 12 jam ,akan menghasilkan membutuhkan daya sebesar :

$0,15 \mathrm{kWh} \times 12 \mathrm{jam}=1,8 \mathrm{kWh} / \mathrm{hari}$

$1,8 \mathrm{kWh} \times 30$ hari $=54 \mathrm{kWh} / \mathrm{bulan}$

Sehingga total tagihan 30 lampu bohlam perbulan dengan $\mathrm{kWh}$ meter $2200 \mathrm{VA}$ dalam sebulan dengan tagihan per-kWh kurang lebih Rp. 1.444,70 akan menjadi sebesar :

54 kWh x Rp. $1.444,70=$ Rp. $78.013,8 /$ bulan.

Sedangkan dalam penggunaaan panel surya akan membutuhkan dana dengan perhitungan sebagai berikut :

1. 30 lampu bohlam 5 watt akan membutuhkan 150 watt untuk perharinya, maka terdapat 1.800 watt beban yang digunakan selama 12 jam perharinya.

2. Akan memberikan keuntungan besar dalam penggunakan panel surya pada malam hari dengan penggunaan baterai relative tidak berat karena hanya membutuhkan beban 1800 watt perharinya, karena terdapat supply dari sinar matahari. Sehingga dibutuhkan supply baterai sebesar : 1800 watt akan memerlukan tambahan beban $20 \%$ untuk perangkat panel surya itu sendiri seperti inverter pengubah arus DC menjadi arus AC, karena pada dasarnya rumahtangga membutuhkan listisk arus bolak balik. Maka total daya yang dibutuhkan sebesar :

$1800+(1800 \times 20 \%)=2.160$ watt

3. Dari total daya 2.160 tersebut maka akan dibuthkan baterai $12 \mathrm{~V}$ dengan arus yang dibutuhkan sebesar 180 Ampere. Sehingga ketika menggunakan baterai 65 Ah $12 \mathrm{~V}$ membutuhkan baterai sebanyak 3 baterai karena2.160: $(65 \times 12)=2,78$, yang dibulatkan menjadi 3 baterai yang dibutuhkan.

4. Pada umumnya panel surya yang digunakan adalah panel surya jenis 100 wp (watt peak) yang dapat bekerja menyerap sinar matahari rata rata selama 5 jam perhari. Sehari didapatkan sebesar 500 watt disetiap panel surya yang ada. Jika dibutuhkan 2.160 watt maka dibutuhkan panel surya sebanyak :

2.160 watt : 500 watt/panel $=4,32$ panel Atau dapat dibulatkan menjadi 5 buah panel surya untuk dapat memenuhi daya 2.160 watt.

5. Sehingga 30 lampu bohlam yang setiap harinya digunakan 12 jam akan membutuhkan baterai 3 buah 65 Ah 12 Vdan 5 buah panel surya 100 wp. Dengan biaya seluruh perangkat antaraRp. 2.000.000 - Rp. 2.500.000 perr 100wp dengan demikian, dana yang dibutuhkan 5 buah panel surya $100 \mathrm{wp}$ yaitu sekitar Rp10Jt -13 Jt.

Akan tetapi dana panel surya tersebut dapat digunakan sekitar 20 tahun, sehingga dalam 20 tahun (480 bulan) akan membutuhkan dana sekitarRp 41.000 - Rp. 55.000 perbulannya.

Sehingga penggunaan panel surya akan menghemat dana sekitar 30 ribu rupiah perbulannya disbanding menggunakan PLN dalam penggunakan listrik pada 30 lampu bohlam yang ada di rumah. 
ISSN: 2528-4002 (media online)

ISSN: 2355-892X (print)

Online: http://e-journal.sari-mutiara.ac.id/index.php/KesehatanMasyarakat

DOI: https://doi.org/10.51544/jkmlh.v6i2.1901

KESIMPULAN

Dapat disimpulkan bahwa 30 lampu bohlam yang ada dirumah membutuhkan dana sekitar Rp. 78.013,8 / bulan, sedangkan dengan menggunakan panel surya membutuhkan dana sekitar Rp 41.000 - Rp. 55.000per bulannya. Sehingga, panel surya dapat mengefisiensi penggunaan listrik dalam segi harga dan energy sebanyak 2.1600 watt diperbulannya dengan menggantikan energy listri dari minyak bumi yang digantikan oleh panas matahari dengan penghematan dalam segi aspek keuangan sebanyak 30 ribu rupiah atau sekitar $38 \%$ dari dana awal yang dibutuhkan disetiap bulannya.

\section{DAFTAR PUSTAKA}

Kidowaki, H., Takeo, O., Tsyuyohi, A., Atsuhi, S., B., J., \&Jhon, C(2012).
Fabrication and Characterization of CuO-based Solar Cells. Journal of Materials Science Research,1(1), 138140.

Mcgehee, Michael, D(2013). Fast- Track Solar Cells . Nature (Vol 501), 323-325.

Sun, Yangmin, Gregory C., W., Wei, L., L., Chirstopher, J., T., Guillermo, C., B., \& Alan, J., H (2012). Solution-processed small-molecule solar cells with $6.7 \%$ efficiency. Naturel Materials (Vol 11), 44-48.

Tiyas, P., Kusumaning, \& M., Widyartono(2020). Pengaruh Suhu Terhadap Kinerja Panel Surya. Jurnal Teknik Elekto.(09)01: 871-876. 